\title{
INTERACTION OF FUNDAMENTAL (HUMAN) RIGHTS AND FUNDAMENTAL (MARKET) FREEDOMS IN THE EU
}

\author{
Tamara Perišin
}

Summary: The issue of balancing free trade with the protection of values, national regulatory autonomy and sovereignty has recently been accentuated in the area of fundamental (human) rights. It is well established case law that fundamental rights are a part of the general principles of Community law protected by the Court, but their precise status in the EU legal order has remained unclear up to the present. Particularly questionable is the issue of the hierarchy of these rights in relation to Treaty provisions. This paper focuses on the interaction between fundamental rights and fundamental (market) freedoms, and it analyses the implications of the case law dealing, on the one hand, with their mutual enhancement and, on the other hand, with their potential conflicts. Both types of cases raise sensitive constitutional issues, because, while supporting fundamental rights protection, there is an occasional lack of concern for other interests that national regulators seek to protect.

\section{Introduction}

The issue of balancing free trade with the protection of values, national regulatory autonomy and sovereignty has recently been accentuated in the area of fundamental (human) rights. ${ }^{1}$ It is well established case law that fundamental rights are a part of the general principles of Community law protected by the Court, ${ }^{2}$ but their precise status in the

\footnotetext{
* Tamara Perišin, MJur (Oxon), Department for European Public Law, Faculty of Law, University of Zagreb. I owe thanks to Tamara Ćapeta, Hano Ernst, Marko Milanović and Siniša Rodin for their comments on earlier drafts, to Daniel Halberstam, Christopher McCrudden, John Morijn, Don Regan, Stephen Weatherill and Derrick Wyatt for useful comments and discussions and to all who provided feedback when elements of this paper were presented at the 4th Jean Monnet Module "Advanced Issues of European Law" in Dubrovnik, at the SJD Colloquium of the University of Michigan Law School, Ann Arbor, and at the 6th Biennial Conference of ECSA-C, Victoria, B.C. Canada.

${ }^{1}$ Hereinafter, fundamental rights or human rights.

${ }^{2}$ The system of fundamental rights protection was absent from the original treaties, and it was developed later on, primarily by the European Court of Justice (ECJ), but also by the Community's "legislative" institutions and through treaty amendments. The reasons which led to this kind of jurisprudence were abundant and multifarious. In my opinion, this development was a necessary corollary of introducing direct effect and supremacy in 1963 and 1964, as there is no doubt that Member States would have found these charac-
} 
EU legal order has remained unclear up to the present. Particularly questionable is the issue of the hierarchy of these rights in relation to Treaty provisions. In the context of the internal market, this issue is relevant because fundamental (market) freedoms ${ }^{3}$ and human rights can interact in many ways. The type of interaction that has recently caused great stir concerns the question of whether fundamental rights protection is a permissible exception to fundamental freedoms, and, if this is so, under what conditions. ${ }^{4}$ Or is it perhaps vice versa, since fundamental freedoms can only operate within the framework of and in accordance with fundamental rights. Consequently, is fundamental rights protection in this case a derogation from Community law or its implementation ${ }^{5}$

In answering these questions "[i]t is significant ... that the Court of Justice should defend fundamental rights as general legal principles of the Community on the basis of Article 220 EC and Article 6(2) EU. They are to be considered part of its primary legislation and therefore rank in hierarchy at the same level as other primary legislation, particularly fundamental freedoms." 6 "It would nevertheless be appropriate to discuss in general the question of whether ... fundamental and human rights could in general be afforded a certain precedence over 'general' primary legislation". ${ }^{7}$

These issues are further complicated by the fact that "fundamental freedoms themselves can also perfectly well be materially categorised as fundamental rights - at least in certain respects: in so far as they lay

teristics of Community law unacceptable if the Community had not committed itself to the observance of fundamental rights which lie at the core of national legal orders. (Case 26/62 NV Algemene Transport- en Expeditie Onderneming van Gend \& Loos v Netherlands Inland Revenue Administration [1963] ECR 1, case 6/64 Flaminio Costa v E.N.E.L. [1964] ECR 585.) One could also speculate on the Court's ulterior motives - resisting pressures from Member States, extending its own jurisdiction, subjecting States to its scrutiny of fundamental rights protection, rivalry with the European Court of Human Rights (ECtHR), etc., but the intent of this paper is to focus on specific questions arising from the fundamental rights' case law, and not to give a complete overview of ECJ's jurisprudence in this area or to provide a thorough analysis of the motives, controversies and pitfalls surrounding it.

${ }^{3}$ Hereinafter, fundamental freedoms or market freedoms.

${ }^{4}$ On the relationship between fundamental rights and fundamental freedoms, see S Weatherill, 'The Internal Market' in S Peers and A Ward (eds), The EU Charter of Fundamental Rights: Politics, Law and Policy (Hart Publishing, Oxford 2004), NN Shuibhne, 'The European Union and Fundamental Freedoms' in P Beaumont, C Lyons and N Walker (eds), Convergence and Divergence in European Public Law (Hart Publishing, Oxford 2002).

${ }^{5}$ See J Morijn, Balancing Fundamental Rights and Common Market Freedoms in Union Law: Schmidberger and Omega in the Light of the European Constitution', (2006) 12 (1) European Law Journal 15, 31-33.

${ }^{6}$ Opinion of Advocate General Stix-Hackl in case C-36/02 Omega Spielhallen- und Automatenaufstellungs-GmbH v Oberbürgermeisterin der Bundesstadt Bonn [2004] ECR I-9609, delivered on 18 March 2004, para 49

7 ibid para 50. 
down prohibitions on discrimination, for example, they are to be considered a specific means of expression of the general principle of equality before the law. In this respect, a conflict between fundamental freedoms enshrined in the Treaty and fundamental and human rights can also, at least in many cases, represent a conflict between fundamental rights." The question whether fundamental market freedoms have the status of fundamental rights has been highly controversial in legal scholarship, ${ }^{9}$ but even if there was a clear answer to it, it would still be unclear how to balance these market freedoms with (other) fundamental rights. ${ }^{10}$ This is firstly because fundamental rights are not absolute, so they can also be restricted under certain conditions, and secondly because not all fundamental rights enjoy the same status. ${ }^{11}$

The EU Charter of Fundamental Rights ${ }^{12}$ has not shed much light on this area, and this is firstly due to the fact that the status of this document has remained uncertain ever since its solemn proclamation in 2000 , and, secondly, because the issue is not explicitly addressed therein. ${ }^{13}$ The Charter has been incorporated into the signed Treaty Establishing a Constitution for Europe, ${ }^{14}$ so the fundamental rights which it guarantees could be reaffirmed as a part of primary EU law if the Constitution comes into force (which currently does not seem likely). However, even this development would not answer the question whether fundamental rights are hierarchically superior to fundamental freedoms.

\footnotetext{
8 ibid.

9 This was particularly controversial in WTO law. See EU Petersmann, Time for a United Nations 'Global Compact' for Integrating Human Rights into the Law of Worldwide Organizations: Lessons from European Integration' (2002) 13 EJIL (2002) 621, R Howse, 'Human Rights in the WTO: Whose Rights, What Humanity? Comment on Petersmann' (2002) 13 EJIL 651, P Alston, 'Resisting the Merger and Acquisition of Human Rights by Trade Law: A Reply to Petersmann' (2002) 13 EJIL 815, EU Petersmann, 'Taking Human Dignity, Poverty and Empowerment of Individuals More Seriously: Rejoinder to Alston' (2002) 13 EJIL 845.

${ }^{10}$ For an analysis of tensions between trade and human rights in the global context and their possible solutions, see C McCrudden, 'International Economic Law and the Pursuit of Human Rights: A Framework for Discussion of the Legality of 'Selective Purchasing' Laws under the WTO Government Procurement Agreement' (1999) JIEL 2, 3, C McCrudden and A Davies, 'A Perspective on Trade and Labour Rights' (2000) JIEL 3, 43.

${ }^{11}$ It is noteworthy that art 16 of the Charter of Fundamental Rights of the European Union (OJ C 364/1, 18 December 2000) guarantees the freedom to conduct a business. The Explanatory Memorandum states that this provision is based on the ECJ's earlier case law, but it remains uncertain whether it can be interpreted to cover fundamental market freedoms. Council of the European Union, 'Charter of Fundamental Rights of the European Union - Explanations relating to the complete text of the Charter' $<$ http://ue.eu.int/docCenter.asp?lang=en\&cmsid=245 $>$ accessed December 2000.

12 Charter of Fundamental Rights of the European Union [2000] OJ C364/1.

${ }^{13}$ So far, the ECJ has never called upon the Charter, but it has frequently been relied upon by Advocates General.

${ }_{14}$ Treaty Establishing a Constitution for Europe [2004] OJ C310.
} 
Similarly, case law does not provide a clear-cut answer to weighing market freedoms with national, international and Community standards of human rights protection (or on the weighing of all these interests with other regulatory preferences). Moreover, it will be shown that the outcome depends on the circumstances of a particular case. It is noteworthy that this is the field of EC law where the case law concerning each of the four fundamental freedoms is relevant for all of them, i.e. where the European Court of Justice (ECJ) is applying its reasoning throughout the four freedoms. Therefore, this paper will touch upon all the freedoms. Until recently, the cases that reached the ECJ dealt only with situations where fundamental rights and fundamental freedoms reinforced one another, or at least where their conflict was not explicit (these cases will be addressed in part II of this paper). In contrast, since the year 2000 there have been several cases where full observance of market freedoms has collided with fundamental rights protection (the cases will be dealt with in part III).

\section{Mutually enhancing (or at least not directly conflicting) fundamental rights and fundamental freedoms}

\section{Preliminary remarks}

One might generally argue that the development of market freedoms and of fundamental rights go hand in hand, but it is not the intention of this paper to analyse the general conditions for the functioning of markets or for the creation of human rights protection mechanisms. What is important here is that the Court has established a system of significant fundamental rights protection by linking these rights to another Community law issue, frequently to a fundamental freedom. This chapter will focus on particular cases where a fundamental freedom and a fundamental right have worked to each other's advantage (as in ERT, ${ }^{15}$ Carpenter $^{16}$ and Karner $^{17}$ ), although in some instances the situation was additionally complicated by the very number of fundamental rights at issue (e.g. in SPUC v. Grogan ${ }^{18}$ and Familiapress ${ }^{19}$ ). I will argue that there can be many positive synergies between fundamental freedoms and fundamental rights,

\footnotetext{
${ }^{15}$ Case C-260/89 Elliniki Radiophonia Tiléorassi AE and Panellinia Omospondia Syllogon Prossopikou v Dimotiki Etairia Pliroforissis and Sotirios Kouvelas and Nicolaos Avdellas and others [1991] ECR I-2925.

${ }^{16}$ Case C-60/00 Carpenter $v$ Secretary of State for the Home Department [2002] ECR I6279 .

${ }_{17}$ Case C-71/02 Herbert Karner Industrie-Auktionen GmbH v Troostwijk GesmbH [2004] ECR I-3025.

18 Case C-159/90 The Society for the Protection of Unborn Children Ireland Ltd and Stephen Grogan and Others [1991] ECR I-4685.

19 Case C-368/95 Vereinigte Familiapress Zeitungsverlags- und vertriebs GmbH v Heinrich Bauer Verlag [1997] ECR I-3689.
} 
but that, in deciding on their preferable scope, consideration should paid to many other values at stake. Namely, positive synergy is not necessarily one that maximises the protection of fundamental rights and fundamental freedoms, but is something that protects them, at the same time leaving enough space for the protection of other legitimate interests. This will be further explained in the case law analysis below.

\section{Case law analysis}

Laying out the standard ERT line of case law

The interplay between fundamental freedoms and fundamental rights in the ERT line of case law is based on the idea that the scope of fundamental freedoms and their possible exceptions should be construed in the light of fundamental rights. This approach was already argued for by Advocate General Slynn in Cinéthèque ${ }^{20}$ and the Court adopted it in ERT. ERT concerned a Greek law granting a television monopoly to a single broadcaster, and the question was whether this Greek law was contrary to the freedom to provide services and whether this freedom had to be appraised in the light of the freedom of expression embodied in Article 10 of the European Convention on Human Rights (ECHR). ${ }^{21}$ The Court took a very important step in respect of the coherence between market freedoms and human rights. It established that all national rules within the scope of Community law, particularly the justifications of State "rules which are likely to obstruct the exercise of the freedom to provide services ... must be interpreted in the light of general principles of law and in particular of fundamental rights". ${ }^{22}$ The scope of the freedom to provide services and of its possible exceptions, such as public policy, public security and public health, had to be interpreted in the light of the freedom of expression guaranteed by Article 10 ECHR. ${ }^{23}$

The Court's approach in ERT did not go without criticism. A common objection was that fundamental rights were being used to enhance market integration since they limited the possibility of justifying restrictions to fundamental market freedoms. The Court itself was aware of this, so in the following case, SPUC $v$. Grogan, it showed caution in extending a fundamental rights review. The case arose in Ireland where abortion is prohibited and where Grogan and several other officers of student asso-

\footnotetext{
${ }^{20}$ Opinion of AG Slynn in 60/61-84 Cinéthèque SA and others $v$ Fédération nationale des cinémas français [1985] ECR 2605, delivered on 20 March 1985.

${ }^{21}$ European Convention for the Protection of Human Rights and Fundamental Freedoms (ECHR), ETS no 5

${ }^{22} \operatorname{ERT}(\mathrm{n} 15)$ para 43.

${ }^{23}$ For a more recent example of the interface between free movement of goods and freedom of expression, see Opinion of Advocate General Alber in Karner (n 17).
} 
ciations were distributing information about abortion clinics in the UK. SPUC (Society for the Protection of Unborn Children) requested a national court to declare that the distribution of the mentioned material was illegal and it sought an injunction to restrain further distribution. ${ }^{24}$ The national court was not certain whether such a decision would be in conformity with Community law, so it made a preliminary reference. The ECJ primarily found that a "medical termination of pregnancy, performed in accordance with the law of the State in which it was carried out" constituted a service within the meaning of the EC Treaty. A more subtle question was whether a prohibition on the provision of information about abortion clinics was contrary to Community law in respect, firstly, of the freedom to provide services and, secondly, the freedom of expression and the freedom to impart and receive information. Concerning the freedom to provide services, the ECJ said there was no economic link between the student associations and the service providers in the UK, resulting in the matter not being within the scope of the EC Treaty. ${ }^{25}$ The lack of an economic link was a crucial difference between the facts of SPUC $v$. Grogan and ERT, and this difference was further reflected in the ECJ's scrutiny over fundamental rights. The Court held that unlike the situation in ERT, "with regard to national legislation lying outside the scope of Community law" "the Court has no such jurisdiction" to "provide the national court with all the elements of interpretation which are necessary in order to enable it to assess the compatibility of that legislation with the fundamental rights". ${ }^{26}$

Another case that elaborated ERT was Familiapress. It extended the ERT reasoning by making clear that measures adopted to achieve a "mandatory requirement" also had to be assessed in the light of general principles of law and in particular of fundamental rights. The case dealt with an Austrian law containing a prohibition of offering consumers free gifts connected with the sale of goods or the provision of services, and it did not allow any exceptions for the press. A German publisher, Heinrich Bauer Verlag, was publishing a magazine "Laura", which contained a crossword puzzle and readers who sent correct solutions could win valuable prizes. "Laura" was sold in Austria, so an Austrian newspaper publisher, Familiapress, brought an action against Heinrich Bauer Verlag on the basis of Austrian law. The question that reached the ECJ was whether this law was compatible with Article 28 EC. The Court rejected the Austrian arguments that the law concerned selling arrangements and held that, since the law required traders from other Member States to

\footnotetext{
${ }^{24}$ SPUC $v$ Grogan (n 18) para 7.

25 ibid paras 25-27.

26 ibid para 31.
} 
alter the contents of the periodical, it impaired their market access and constituted a measure having equivalent effect to quantitative restrictions (Article 28 EC).

The interplay between fundamental rights and fundamental freedoms again appeared in the assessment of justification, since the Austrian government invoked the mandatory requirement of maintaining press diversity.$^{27}$ It was emphasised that the situation in Austria was specific due to an unusually high degree of concentration of the press, ${ }^{28}$ and that the law was adopted to prevent competition in which publishers offered larger and larger gifts which could, consequently, eliminate small publishers. ${ }^{29}$ One should notice that the question whether the Austrian law could be justified on grounds of press diversity was ambiguous in respect of fundamental rights protection. On the one hand, the law was enhancing press diversity as a means of facilitating the freedom of expression, protected by Article 10 ECHR. In this respect, Familiapress could be considered as the first case where fundamental rights were grounds for justifying a restriction of the free movement of goods, albeit indirectly (in contrast to Schmidberger ${ }^{30}$ and Omega ${ }^{31}$ where a fundamental right was directly invoked to justify a restriction of a fundamental freedom). ${ }^{32}$ On the other hand, the law limited publishers, such as Heinrich Bauer Verlag, who wanted to offer free gifts to their consumers, in their freedom of expression, particularly in the right to commercial speech.

It is important that the ECJ assessed the scope of the suggested justification in the light of the ECHR and of the practice of the European Court of Human Rights (ECtHR). It established that according to the practice of the ECtHR, the Convention permits derogations from the freedom of expression for the purposes of preserving press diversity, in so far as they are prescribed by law and necessary in a democratic society. ${ }^{33}$ Finally, the Court provided the national court with guidelines to as-

\footnotetext{
${ }^{27}$ Familiapress (n 19) para 13.

28 ibid para 17.

29 ibid paras 14-16.

${ }^{30}$ Case C-112/00 Eugen Schmidberger, Internationale Transporte und Planzüge and Republik Österreich [2003] ECR I-5659.

${ }^{31}$ Case C-36/02 Omega Spielhallen- und Automatenaufstellungs-GmbH v Oberbürgermeisterin der Bundesstadt Bonn [2004] ECR I-9609.

${ }^{32}$ MP Maduro, 'The Saga of Article 30 EC Treaty: To Be Continued - A Comment on Familiapress v. Bauer Verlag and Other Recent Episodes' (1998) 5 Maastricht Journal of European and Comparative Law 311.

${ }^{33}$ Familiapress (n 19) para 26. The ECJ explicitly relied on the decision of the ECtHR in Lentia (Informationsverein Lentia and Others $v$ Austria (App no 13914/88, 15041/89, 15717/89, 15779/89, 17207/90) (1993) Series A no 276, and Advocate General Tesauro (Opinion of Advocate General Tesauro in Familiapress (n 19), delivered on 13 March 1997) also called upon several other cases explaining permissible restrictions to freedom of ex-
} 
sess whether the law was proportionate "to the aim of maintaining press diversity and whether that objective might not be attained by measures less restrictive to both intra-Community trade and the freedom of expression". ${ }^{34}$

Pros and cons of the ERT line of case law

The Court's approach in ERT was criticised on the grounds that it was using fundamental rights for the enhancement of market integration by limiting the possibility of justifying restrictions to fundamental market freedoms.

However, I tend to agree with Weatherill who notices that the case law, particularly SPUC v. Grogan, demonstrates that the Court "is alert to the dangers of "over-marketising' policy sectors" and that "it was willing in cases it deems appropriate to find reasons to treat national choices as falling outwith the scope of application of the relevant Treaty provisions altogether. The reach of trade law tends to spill over into ever wider sectors. The Court is not oblivious to the dangers this presents." ${ }^{35}$ The ECJ's reasoning in SPUC $v$. Grogan illustrates its awareness of the subtleties in balancing all the values concerned, such as the freedom to impart and receive information, the freedom of expression, the right to life and the right to privacy, as well as the implication of this question on the free movement of services. The ECJ considered that the case was so remotely connected to the provision of services that the balancing of the values at stake was to be left to national regulators. One can only speculate how the Court would have decided the case if medical clinics from the UK, i.e. the foreign service providers themselves, were the ones distributing the information in Ireland.

The Court's reluctance to engage in the assessment of the Irish regulatory choice becomes even more visible in the light of the fact that its decision did not follow the opinion of the Advocate General. Namely, unlike the Court, Advocate General Van Gerven considered that "Community citizens derive from [the Treaty provision of free movement of services] the

pression (The Sunday Times $v$ The United Kingdom(App no 6538/74) (1979) Series A no 30; Lingens $v$ Austria (App no 9815/82) (1986) Series A no 103 etc.). The approach of the Court where it wants to give fundamental rights in the Community the same meaning and scope as the ECtHR is particularly relevant in respect of the Charter of Fundamental Rights of the EU which provides that "[i]n so far as this Charter contains rights which correspond to rights guaranteed by the Convention for the Protection of Human Rights and Fundamental Freedoms, the meaning and scope of those rights shall be the same as those laid down by the said Convention" (art 52). The Court's practice of following the decisions of the ECtHR will become even more relevant if the Constitutional Treaty comes into force and if, in accordance with it, the EU accedes to the Convention.

${ }^{34}$ Familiapress (n 19) para 27.

35 Weatherill (n 4) 188. 
right to obtain information regarding services lawfully provided in another Member state just as they derive the right therefrom to distribute such information, whether or not for remuneration". ${ }^{36}$ Thus, in his opinion, the national measure was within the scope of Community law and was in principle contrary to Articles 59 and 60 EC (now Arts. 49 and 50 EC). In his further analysis, he found that the measure was justified and that the justification was in accordance with fundamental rights, specifically with the freedom of expression and the right to life embodied in the ECHR.

Criticism of the ERT reasoning still persists. For example, Advocate General Jacobs argued extra-judicially that once a restriction is justified under one of the permissible derogations, the question whether the restriction infringes a fundamental right is not one of Community law. ${ }^{37}$ He suggested that the time had come for the ECJ to make a distinction between fundamental rights and some other general principles of Community law. Under that approach, national derogations from fundamental freedoms would be subject to the constraints imposed by Community law concerning respect for general principles such as non-discrimination and proportionality. On the contrary, Community law would not impose such constraints on national derogations by requiring them to protect fundamental rights. ${ }^{38}$

It is easy to ask what the logic and policy would be in distinguishing these different principles of Community law. Of course, it derives already from Article $30 \mathrm{EC}$ that the ECJ is required to assess the justification (contained therein), proposed by a Member State, in the light of proportionality and non-discrimination. Therefore, it seems that the underlying rationale of the distinction derives from the question whether Member States are committed to the protection of a particular principle at stake by their own constitutional order or by EC law. So, on the one hand, States themselves are trying to achieve fundamental rights protection, and sources of fundamental rights protection in the Community are precisely their common constitutional traditions and the Convention on Human Rights to which all Member States are parties (as well as other international treaties to which Member States are parties or in which they have collaborated). ${ }^{39}$ On the other hand, Member States' legal orders

\footnotetext{
${ }^{36}$ Opinion of Advocate General Van Gerven in SPUC $v$ Grogan (n 18), delivered on 11 June 1991, para 21.

${ }^{37}$ FG Jacobs, 'Human Rights in the European Union: the role of the Court of Justice' (2001) 26 ELR 331, 336-337.

${ }^{38}$ For similar reasoning, see M Avbelj, 'European Court of Justice and the Question of Value Choices - Fundamental human rights as an exception to the freedom of movement of goods' (2004) Jean Monnet Working Paper 06/04, NYU School of Law, 76-78.

${ }^{39}$ Case 11/70 Internationale Handelsgesellschaft $\mathrm{mbH} v$ Einfuhr-Voratsstelle fur Getreide und Futtermittel [1979] ECR 1125, case 4/73 Nold KG v Commission [1974] ECR 491.
} 
might not, independently of Community law, commit them to guarding the principles of proportionality and non-discrimination as understood by EC law. Therefore, there is logic in claiming that there is no need for the ECJ to intervene in the former case, while it should certainly do so in the latter. In my opinion, though, the interaction of Community law and national legal orders might create situations which would not be easily reviewed by the traditional national systems of fundamental rights protection (e.g. residual situations, discussed below). Therefore, significant effects might come from maintaining the Court's review of fundamental rights in situations that are a consequence of applying or of disapplying Community law.

It is not clear whether the EU Charter narrows down the ERT formula or whether it confirms it. Namely, Article 51 (1) Charter states that its provisions "are addressed to institutions and bodies of the Union ... and to the Member States only when they are implementing Union law." The question here arises: what does "implementing" Union law mean? In one view, this provision, taken on its own, could suggest that the Charter does not apply when Member States are "derogating" from Union law. That reading would be contrary to the ERT judgement. However, a different interpretation can be derived from the explanatory memorandum to the Charter. It says that "[a]s regards the Member States, it follows unambiguously from the case-law of the Court of Justice that the requirement to respect fundamental rights defined in a Union context is only binding on the Member States when they act in the context of Community law"40 The phrase "act in the context of Community law" would leave enough space for maintaining the ERT formula. It is noteworthy that the Constitutional Treaty incorporated this provision of the Charter in its present form, so the questions surrounding the issue remain. ${ }^{41}$

\section{Where to go and where not to go beyond ERT?}

The case that perhaps went the farthest in developing synergy between fundamental rights and fundamental freedoms is Carpenter. ${ }^{42}$ Mary (later with the married name Carpenter) was a national of the Philippines who legally entered the UK, but overstayed her leave to reside in the UK and failed to apply for an extension of her stay. When she reappeared before British authorities she was married to a British national, Peter Carpenter. Their marriage was genuine, but according to UK law Mary

${ }^{40}$ Council of the European Union, 'Charter of Fundamental Rights of the European Union - Explanations relating to the complete text of the Charter' <http://ue.eu.int/docCenter. asp?lang=en\&cmsid=245> accessed December 2000 .

${ }^{41}$ Treaty Establishing a Constitution for Europe (n 14) art II-111.

${ }^{42}$ For the comment of Carpenter see S Acierno, 'The Carpenter judgment: fundamental rights and limits of the Community legal order' (2003) 28 ELR 398 
Carpenter still had to be deported. Therefore, the Carpenters decided to challenge the legality of the deportation. The case was referred to the ECJ because Peter Carpenter ran a business established in the UK and provided a significant proportion of services to recipients in other Member States. This cross-frontier provision of services triggered the applicability of Community law, so Mr Carpenter was able to avail himself of the right guaranteed under Article $49^{43}$ EC (especially since the Court had already established that this Article could be relied upon against the State in which a provider was established ${ }^{44}$ ). To the surprise of many commentators, the Court concluded that the deportation would be contrary to Article $49 .{ }^{45}$ It said that the separation would be detrimental to the family life of the Carpenters and "to the conditions under which Mr Carpenter exercises a fundamental freedom. That freedom could not be fully effective if Mr Carpenter were to be deterred from exercising it by obstacles raised in his country of origin to the entry and residence of his spouse. That freedom could not be fully effective if Mr Carpenter were to be deterred from exercising it by obstacles raised in his country of origin to the entry and residence of his spouse". ${ }^{46}$ The Court invoked ERT by considering that the UK's public interest in justifying the measure had to be compatible with fundamental rights. ${ }^{47}$ In other words, the Carpenter family was primarily protected through the fundamental freedom to provide services, and incidentally also by the right to family life.

It is true that the reasoning in Carpenter gave outstanding protection to both the freedom to provide services and to the fundamental right at stake, but I will argue that this was done at too great a cost.

Firstly, in respect of the freedom to provide services in Carpenter, the Court determined that Article $49 \mathrm{EC}$ was breached by a measure that was merely "detrimental" to the conditions under which a fundamental freedom was exercised. One should notice that a similarly broad understanding of the Treaty has been adopted in some recent cases on the free movement of capital ${ }^{48}$ where the ECJ extended Article 56 to cover measures deterring or dissuading the exercise of this fundamental freedom. In my opinion, these interpretations of the Treaty are too broad. On the

\footnotetext{
${ }^{43}$ Free movement of services.

${ }^{44}$ The ECJ determined in earlier cases that a service provider could call upon art 49 against his State of establishment. Case C-384/93 Alpine Investment BV v Minister van Financien [1995] ECR I-1141.

45 Carpenter (n 16) para 46.

46 ibid para 39.

47 ibid para 40.

${ }^{48}$ Case C-483/99 Commission v France [2002] ECR I-4781, case C-503/99 Commission $v$ Belgium [2002] ECR I-4809, case C-98/01 Commission v United Kingdom [2003] ECR I4641.
} 
one hand, there is no benefit for market integration in the scrutiny of national measures which are so distant from the issue of free movement. On the other hand, the consistent application of this reasoning could have significant costs and could lower many national standards (such as those connected with immigration control which were at stake in Carpenter). Namely, the interpretation would leave hardly any room for national regulation, and this is not only worrisome per se, but is even more so in situations where there is no Community competence, i.e. where a supranational measure could not fill the regulatory void. Measures which are merely detrimental to the conditions of exercising a fundamental freedom are in my opinion exactly the kind of measures which the Krantz test of "too uncertain and indirect effect" should exclude from the scope of the Treaty. ${ }^{49}$ It is reassuring in that respect that the Krantz test, originally used in the free movement of goods, was subsequently cross-applied to cases involving other fundamental freedoms. ${ }^{50}$

Secondly, in respect of fundamental rights protection in Carpenter, the decision may seem as a continuation of the Court's efforts to prove its sensitivity to human rights protection. One can further speculate that the ECJ achieved a higher standard of protection than would have been granted to the Carpenter family by the ECtHR. ${ }^{51}$ In any case, regardless

${ }^{49}$ Case C-69/88 H Krantz GmbH \& Co. v Ontvanger der Directe Belastingen and Netherlands State [1990] ECR I-583.

${ }^{50}$ For example in cases C-418/93 Semeraro Casa Uno Srl $v$ Sindaco del Commune di Erbusco etc. [1996] ECR I-2975 and C-190/98 Volker Graf v Filzmoser Maschinenbau GmbH [2000] ECR I-493.

${ }^{51}$ We can only speculate, but it is possible that the ECtHR would have found the measure to be justified. Had the Carpenter case come before the ECtHR, the disputed national measure could have been challenged on the grounds of breach of the right to family life (art 8 ECHR). However, that right can be limited in the general interest (art 8(2)) under three conditions - if the limitation is in accordance with the law, if it pursues one of the legitimate aims listed in the Article (national security, public safety or the economic well-being of the country, for the prevention of disorder or crime, for the protection of health or morals, or for the protection of the rights and freedoms of others) and if it is necessary in a democratic society. The situation with the first condition is clear - the measure at stake was in accordance with the law. Concerning the second condition, it seems that the UK's interest in preventing illegal immigration could well be a part of several legitimate aims listed in art 8(2). Finally, the third condition in fact calls for a proportionality test, and it is possible that the ECtHR would have found it to be met since the deportation of Mrs. Carpenter would not have been permanent and she could have reapplied to enter the UK. In any case, the comparative advantage of human rights protection by the ECJ in the Carpenter case is that the case could reach the ECJ regardless of whether all national legal remedies had been exhausted or not. The ECtHR has not had a case resembling Carpenter, but there have been several cases where deportations were challenged on the basis of article $8 \mathrm{ECHR}$, and the ECtHR found the measures to be justified under art 8(2). See, for example, Boujilifa $v$ France, (App no 25404/94) (1997) ECHR 1997-VI; Bouchelkia v France (App no 23078/93) (1997) ECHR 1997-I. In Chahal $v$ the United Kingdom (App no 22414/93) (1996) ECHR 1996-V, the ECtHR held that it was unnecessary to consider the applicants' complaint under article 8 of the Convention since it had already found a breach of other rights protected by the ECHR. 
of what we might think the outcome of the case should be, the question raised is who should have the final authority in this matter - the UK, the ECtHR or the ECJ? The ECJ said in SPUC $v$. Grogan that it had no such jurisdiction to assess the compatibility of national legislation with the fundamental rights where national legislation is outside the scope of Community law. ${ }^{52}$ In my opinion, the measure in Carpenter should have been considered as lying outside the scope of Community law because it had "too uncertain and indirect effect" on free movement. Consequently, the Court should not have assessed the measure in the light of fundamental rights.

There have been good attempts to explain this on the basis of Union citizenship by saying that this concept might give the ECJ the legitimacy to protect an "individual from disproportionate regulations imposed by Member States regardless of an effect, even only potential, on the exercise of intra-Community economic activity". ${ }^{53}$ If that is the case, then it is odd that only citizens exercising a cross-border fundamental freedom enjoy the ECJ's protection. However, even if somehow all citizens would gain the same protection (e.g. by extending the principle of non-discrimination) the question is whether the ECJ should scrutinise measures which are so remotely connected to the internal market.

To conclude the analysis of Carpenter, the Court's reasoning broadened the scope of both the fundamental freedom and of the fundamental right at stake and led to a happy end in the concrete case. However, I do not regard this synergy of fundamental rights and fundamental freedoms to be a positive one. By bringing the situation which was so remotely connected to Community law within its scope, and by subjecting the issue to the ECJ's scrutiny, the case law went beyond and even against the interests of market integration. Firstly, the approach in Carpenter is not sensitive enough to national choices in protecting other legitimate interests (in this case, the UK's control of immigration). Striking down national measures in areas where there is no Community competence to achieve their aim could render the whole EC system unsustainable. Secondly, further application of this approach would clearly increase the workload of the ECJ so the Court would have to redirect its resources towards solving issues only remotely connected with European law. For all these reasons, the Carpenter approach could threaten the legitimacy of the Community's legal system.

As I have pointed out, one of the implications of Carpenter is that it blurred the distinction between on the one hand national measures

\footnotetext{
${ }^{52}$ SPUC $v$ Grogan (n 18) para 31.

53 E Spaventa, 'From Gebhard to Carpenter: Towards a (Non-)Economic European Constitution' (2004) 41 Rev 743, 768.
} 
within the scope of Community law whose compatibility with fundamental rights the ECJ should assess (ERT-type measures), and on the other hand national measures lying outside the scope of Community law for which the Court should not be making that assessment (SPUC-type measures). The distinction is blurred because it becomes completely unclear where the scope of Community law ends (if anywhere). The Karner case clouded this distinction even further.

The contested legislation in Karner prohibited, "irrespective of the truthfulness of the information ... any reference to the fact that goods come from an insolvent estate where, in public announcements or notices intended for a large circle of persons, notice is given of the sale of goods which originate from, but no longer constitute part of, the insolvent estate". ${ }^{54}$ On the one hand, regarding the free movement of goods, the Court established that the disputed national provision was not caught by Article 28. On the other hand, the ECJ did not even assess the measure's compatibility with the free movement of services because it considered that, in the circumstances of the case, since the exercise of that freedom was secondary to the exercise of the free movement of goods, that there was no need to consider the measure in the light of Article 49. ${ }^{55}$ However, quite surprisingly, the Court still engaged in assessing the compatibility of the measure with fundamental rights. It repeated that, according to the settled case law, its task was to "give the national court all the guidance as to the interpretation necessary to enable it to assess the compatibility of that legislation with the fundamental rights" if the measure at hand "falls within the field of application of Community law". ${ }^{56}$ Unfortunately, the Court did not tell us how it was possible for the situation in Karner to be in the "field of application of Community law" given its lack of connection with any of the fundamental freedoms. Namely, a question that goes unanswered is what triggers the Court's review of fundamental rights in this case. However, if it is not possible to identify what triggers the review, is it then possible that all national measures can be subjected to it?

It is true that the Court in Karner recognised the State's discretion, emphasised the complex and fluctuating character of advertising, and found the law to be compatible with the freedom of expression. Consequently, one might say that this judgement did not put any additional constraints on national regulatory autonomy. However, it is my opinion that the judgement is not only flawed from the perspectives of clarity, coherence of the law, and methodology, but also because it places the Court

\footnotetext{
${ }^{54}$ Karner (n 17) para 17.

55 ibid paras 43, 45-47. For a comment of Karner, see J Stuyck, 'Case C-71/02, Herbert Karner Industrie-Auktionen GmbH v. TroostwijkGmbH, Judgment of the Fifth Chamber of 25 March 2004' (2004) 41 CMLRev 1683.

${ }^{56}$ Karner (n 17) para 49.
} 
in the inappropriate role of reviewing compliance with the fundamental rights of measures not connected with Community law. This is not in the best interest of the Union.

This criticism of the Court's approach in Carpenter and Karner does not mean that there are no other situations in which I would find it useful to further develop synergies of fundamental rights and fundamental freedoms. An example of a useful development can be found in the recent opinion in Carbonati Apuani where Advocate General Maduro argued for an extension of the ERT principle to "residual situations" when these fall within the scope of Community law. ${ }^{57}$ Namely, it is well known that Community law does not apply to internal situations, and that States are allowed to discriminate against their own products and nationals (reverse discrimination). ${ }^{58}$ However, Maduro suggests that in internal situations where discrimination is created solely as a consequence of the interaction of Community law and national law, i.e. where discrimination is the result of applying Community law, the remaining national measure should also be interpreted in the light of the general principles of Community law, especially fundamental rights. ${ }^{59}$

Although the case concerned a pecuniary restriction on the free movement of goods, the opinion of the Advocate General is relevant to understand the connections between fundamental freedoms and fundamental rights in general. The question was raised "on the compatibility with Community law of a tax collected on goods transported out of" 60 an Italian municipality, and which was "levied in the same way on goods exported" 61 to other parts of Italy as those exported to other Member States. According to the classical solution, a tax "collected on the occasion of crossing of the frontier, even an internal frontier ... is capable of constituting a charge having equivalent effect to a customs duty". ${ }^{62}$ Maduro considers this to be unsatisfactory.

The standpoint of the Advocate General is that even in respect of the tax imposed on goods which remained in Italy, the situation is not completely outside the scope of Community law. ${ }^{63}$ The interaction of Community law on the free movement of goods and of State law would create discrimination since national legislation would have to be disapplied in

\footnotetext{
57 Opinion of Advocate General MP Maduro in C-72/03 Carbonati Apuani Srl $v$ Comune di Carrara [2004] ECR I-8027, delivered on 6 May 2004, para 65.

58 See, for example, C-448/98 Criminal proceedings against Jean-Pierre Guimont [2000] ECR I-10663

59 Opinion of Advocate General M. P. Maduro in Carbonati Apunani (n 57) para 65.

60 ibid para 2.

61 ibid para 2.

62 ibid para 3.

63 ibid para 60.
} 
so far as it affects Community trade. This would mean that "products covered by that legislation [would] be subject to different systems" "depending on their destination". ${ }^{64}$ Maduro recognises that for a measure to fall within the scope of Community law it is not sufficient that a situation arises from the application of that law, but rather that "[i]t must also be demonstrated that it infringes one of the specific objectives of the Treaty". ${ }^{65} \mathrm{He}$ argues that the Treaty objectives have been extended, and that one of the aims of the Treaty is that no discrimination should arise from the application of Community law. ${ }^{66}$ Consequently, the situation at stake lies within the scope of Community law ${ }^{67}$ and should be "interpreted in the light of the general principles of law and in particular of fundamental rights" 68 as well as in the light of the principle of non-discrimination which should have a scope and existence independent of the rules on free movement. 69

It is difficult to draw the line in respect of guarding fundamental freedoms and fundamental rights, but it is necessary to keep in mind that the ECJ is neither a court of human rights nor a national constitutional court and that it has no independent jurisdiction to decide on human rights violations, as was recently confirmed in Vajnai Attila. ${ }^{70}$ The

\footnotetext{
64 ibid para 61.

65 ibid para 63.

66 ibid para 63.

67 ibid para 64.

68 ibid para 65.

69 ibid paras 67,68 . It is worth noting that the ECJ approached the case differently. It considered that article 23 EC must be read in conjunction with article 14(2) EC which defines the internal market as "an area without internal frontiers in which the free movement of goods, persons, services and capital is ensured" and does not draw any distinction between inter-State frontiers and frontiers within a State. It also repeated that "a charge imposed when goods cross a territorial boundary within a Member State constitutes a charge having effect equivalent to a customs duty". The tax at stake was found to be a "charge having effect equivalent to a customs duty on exports within the meaning of Article $23 \mathrm{EC}$, despite the fact that it is imposed also on goods the final destination of which is within the Member State concerned". Carbonati Apunani (n 57) paras 23-26, 44.

${ }^{70}$ In Vajnai Attila (the Red Star case), a Hungarian court asked whether a provision of Hungarian law "which provides that a person who uses or displays, in public, the symbol consisting of a five-pointed red star commits - where the conduct does not amount to a more serious criminal offence - a minor offence" is "compatible with the fundamental Community-law principle of non-discrimination? Do Article 6 TEU, according to which the Union is founded on the principles of liberty, democracy, respect for human rights and fundamental freedoms, Directive 2000/43/EC, which also refers to fundamental freedoms, and Articles 10, 11 and 12 of the Charter of Fundamental Rights, allow a person who wishes to express his political convictions through a symbol representing them to do so in any Member State?" (Reference in [2004] OJ C262, 15) The Court held that "Mr Vajnai's situation is not connected in any way with any of the situations contemplated by the provisions of the treaties and the Hungarian provisions applied in the main proceedings are outside the scope of Community law", so that the ECJ has no jurisdiction to provide the national court with "the guidance as to interpretation necessary to enable it to assess the compatibility of those pro-
} 
lack of jurisdiction should not be circumvented by broadening the scope of market freedoms so that they would bring almost all situations within the realm of Community law and that the Court could adjudicate on human rights protection. However, the analysis shows that there are still instances in which it would be legitimate for the Court to extend its review of fundamental rights protection.

\section{Conflict of fundamental rights and fundamental freedoms}

\section{Preliminary remarks - possible approaches}

In cases involving a conflict between fundamental rights and fundamental freedoms, the Court has had many possibilities for weighing these interests. The first option would be to consider fundamental rights protection as part of the justifications provided for in Article $30 \mathrm{EC}$, i.e. to treat it as included in the concept of either public morality, public policy, or as an unwritten public interest ground..$^{71}$ The second option would be to understand fundamental rights as a mandatory requirement. However, the problem with this solution would be that, as the law stands, fundamental rights could not be used to justify discriminatory state measures. To my mind, this would be wrong because human rights are such an important interest recognised both by the Community and the States that they should be able to present a legitimate justification even for measures discriminating against imported goods. In other words, if the protection of these rights necessitates the adoption of a national measure discriminating against imports, the measure should not be considered to breach the EC Treaty. Subsequently, the second option should be rejected - fundamental rights should not fall within the category of mandatory requirements, at least not until the Court changes its approach towards mandatory requirements. The third option is to consider fundamental rights as a separate type of justification based on the idea that the protection of these rights is a part of Community law, so when States restrict the free movement of goods in order to protect fundamental rights, they are in fact implementing Community law and not derogating from it. ${ }^{72}$

It has been argued that establishing a clear hierarchy between fundamental rights and fundamental freedoms might become crucial. ${ }^{73}$

visions with the fundamental rights whose observance the Court ensures". Case C-328/04 Criminal proceedings against Attila Vajnai [2005] ECR I-8577 paras 12-14.

${ }^{71}$ Morijn (n 5) p 39.

${ }^{72}$ For an analysis of the difference between derogation and implementation of Community law in connection to human rights, see Morijn (n 5) pp 31-33.

${ }^{73}$ C. Brown, 'Case note - Case C-112/00 Eugen Schmidberger, Internationale Transporte und Pflanzüge v. Austria, Judgement of 12 June 2003, Full Court' (2003) 40 CMLRev1499, 1507-1508. 
While I recognise that this is an important methodological step which might also be helpful for national and Community authorities, it is also my impression that the tensions concerning this issue are overestimated. It has been shown that there are two options in dealing with conflicts of fundamental rights and fundamental freedoms. ${ }^{74}$ Under the first option, free movement is the principal rule and those wishing to restrict it in order to protect a fundamental right have to justify the restriction. ${ }^{75}$ The second option is the opposite - fundamental rights are the principal rule and their limitations aimed at free movement have to be justified. ${ }^{76}$

The choice between these alternatives could have two noteworthy implications, but these would only occasionally become relevant. One implication derives from the fact that each of the two alternatives imposes the burden of proof on a different party, in turn tilting the balance between fundamental rights and fundamental freedoms in distinct directions. ${ }^{77}$ Under the standard approach of the ECJ where fundamental freedoms are the principal rule, the balance would be tilted in their favour and to the disadvantage of fundamental rights. Bearing in mind that the ECtHR has the opposite approach, the possibility of these courts reaching different solutions in the same case is slightly increased. However, the difference in the burden of proof only becomes crucial when equally strong arguments and evidence exist on both sides. This fact mitigates the tilt in the balance between fundamental rights and fundamental freedoms, as well as the possibility of divergence in the ECJ's and the ECtHR's jurisprudence. The other implication of choosing the principal rule is that a measure restricting free movement which was adopted for reasons of human rights protection would be considered to constitute a "prima facie breach" of Community law. I understand the arguments that this language "suggests that, even if the restriction is ultimately justified, it remains something which is at its heart 'wrong', but tolerated". ${ }^{78}$ However, in my opinion, this is simply a matter of standard legal terminology and the result of an absence of a more appropriate expression. There does not have to be anything "wrong" at the heart of the measure, and we can see this not only in cases concerning fundamental rights, but also in all cases where an Article 30 derogation or a mandatory requirement is used. If a trade restrictive measure is justified on the basis, for example, of public health or environmental protection, there should be no feeling that there is a "wrong" inherent in this measure.

\footnotetext{
${ }^{74}$ See ibid 1507-1508 and G Gonzales, 'EC Fundamental Freedoms v. Human Rights in the Case C-112/00 Eugen Schmidberger v. Austria [2003] ECR I-5659' (2004) 31(3) Legal Issues of Economic Integration 219, 226.

75 ibid.

76 ibid.

77 Brown (n 73) p 1508.

78 ibid.
} 
The following analysis of the case law will show that the ECJ has not yet adopted a clear approach to weighing fundamental rights and fundamental freedoms, and it does not seem willing to balance these categories as such. Rather, the Court seems to be adopting a case-by-case approach where the balancing depends on the circumstances of the case. This approach leaves room for national choices in human rights protection, but also places a great deal of responsibility on national courts, and is likely to cause many new references to the ECJ.

\section{Case law analysis}

More intensive debate on the possible conflicts between fundamental freedoms and fundamental rights was brought about by the dispute known as the Spanish Strawberries case. ${ }^{79}$ French farmers were protesting against agricultural products from other Member States, especially Spanish strawberries, and private individuals committed a series of violent acts against importers. The Commission brought an action against France, and the Court found that Article 28 "also applies where a Member State abstains from adopting the measures required in order to deal with obstacles to the free movement of goods which are not caused by the State". ${ }^{80}$ This was the first time that an omission of a State fell foul of Article 28, and it raised many questions regarding the extent to which States might be responsible for inaction when private persons create obstacles to trade. Although no one in this case argued that French farmers were exercising a fundamental right, an important question arose about whether a State could be found in violation of Article 28 in situations where private persons created obstacles to the free movement of goods by exercising their fundamental right, such as the right to strike.

The issue was addressed in Regulation $2679 / 98^{81}$ which was adopted in the aftermath of Spanish Strawberries. The Regulation reiterates that an obstacle to the free movement of goods can involve either the action or inaction of a State ${ }^{82}$ and it emphasises that "Member States should, on the one hand, abstain from adopting measures or engaging in conduct liable to constitute an obstacle to trade and, on the other hand, take all necessary and proportionate measures with a view of facilitating free movement of goods in their territory", ${ }^{83}$ but it also explicitly provides

\footnotetext{
79 C-265/95 Commission v France [1997] ECR I-6959.

80 ibid para 30.

${ }^{81}$ Council Regulation (EC) 2679/98 of 7 December 1998 on the functioning of the internal market in relation to the free movement of goods among Member States [1998] OJ L337.

82 Article 1 Regulation (EC) 2679/98.

83 Preamble Regulation (EC) 2679/98.
} 
that "such measures must not affect the exercise of fundamental rights, including the freedom to strike". ${ }^{84}$

The first case where fundamental freedoms explicitly came into conflict with the protection of fundamental rights in a way that a Member State invoked the necessity of protecting the latter in order to justify a restriction on the former was Schmidberger ${ }^{85}$ Fundamental rights were here directly invoked to justify a restriction on the free movement of goods, and not merely to assess the validity of another justification (either from Article 30 or a mandatory requirement) as was the case in ERT and Familiapress. ${ }^{86}$

The Schmidberger case arose when Austrian authorities allowed an association for the protection of the biosphere in the Alpine region ${ }^{87}$ to demonstrate on the Brenner motorway, during which time the motorway had to be closed to traffic. This motorway was the "main, if not the only, intra-Community route" 88 in the Alpine region "available for heavy goods vehicles without a considerable detour" 89 so, due to the demonstration,

${ }^{84}$ Preamble Regulation (EC) 2679/98, and similarly in art 2 Regulation (EC) 2679/98.

85 There was an earlier case of potential conflict between national rules aimed at human rights protection on the one hand and free movement rules on the other hand, but the latter concerned a Regulation and not EC Treaty provisions. The Court in Adidas found that Regulation 3295/94 (laying down measures to prohibit the release for free circulation, export, re-export or entry for a suspensive procedure of counterfeit and pirated goods) precluded national law under which the identity of the declarants or consignees of imported goods which the trademark owner found to be counterfeit might not be disclosed to him. Advocate General Cosmas discussed whether the provisions of the Regulation on disclosing the mentioned information to the trademark holder was compatible "with the fundamental rules and general principles of Community law. In particular... the extent to which the disclosure of the name and address of the declarant and the consignee of goods whose authenticity has been checked is consistent with the fundamental rules on the protection of private life and free development of the personality" (para 34). After conducting an analysis of conditions for restricting these fundamental rights, Cosmas concluded that "the Community legislator has properly balanced the existing interests, on the one hand the interests of the declarant and the consignee of goods and on the other the interests of the trade-mark holder and the market in general" (para 41). The question is what would have happened if the State was not satisfied with the level of fundamental rights protection achieved by the Regulation and if it had insisted upon its own, higher level of protection of the rights at stake. These kinds of questions will be discussed further in the analysis of the Schmidberger and Omega cases. Case C-223/98 Adidas AG [1999] ECR I-7081, Opinion of Advocate General Cosmas, in C223/98 Adidas AG, delivered on 10 June 1998.

${ }^{86}$ For a comparison of the Schmidberger case with earlier case law, see F Ronkes Agerbeek, 'Freedom of Expression and Free Movement in the Brenner Corridor: The Schmidberger Case' (2004) 29(2) ELR 255, 262-263; also A Biondi, 'Free Trade, A Mountain Road and the Right to Protest: European Economic Freedoms and Fundamental Individual Rights', (2004) 1 EHRLR 51, 55-58.

87 Schmidberger (n 30) para 10.

${ }^{88}$ Opinion of Advocate General Jacobs in Schmidberger (n 30), delivered on 11 July 2002, para 2.

89 ibid. 
heavy goods vehicles were immobilised for more than 30 hours. Schmidberger, a transport company whose vehicles were prevented from using the motorway during the demonstration, brought an action for damages against Austria. The question that the ECJ had to answer was whether in these circumstances the closing of the Brenner motorway for 30 hours amounted to a restriction of the free movement of goods and, if so, whether the restriction was justified.

The Court had no difficulty in establishing that the conduct of the Austrian authorities was a measure of equivalent effect to a quantitative restriction on the free movement of goods because it was settled in the case law that, firstly, rules on the free movement of goods apply not only to imports and exports, but also to transit, and, secondly, that a state omission can also be contrary to Article 28 EC. ${ }^{90}$ The ECJ said that this measure was, in principle, incompatible with Articles 28 and 29, unless the failure to ban a demonstration was objectively justified. ${ }^{91}$

Turning to the analysis of the justification, I explained above that there are at least three possibilities of weighing fundamental rights and fundamental freedoms. However, the Court in Schmidberger did not explicitly select one of them, but merely said that "since both the Community and its Member States are required to respect fundamental rights, the protection of those rights is a legitimate interest which, in principle, justifies a restriction of the obligations imposed by Community law, even under a fundamental freedom ... such as the free movement of goods". ${ }^{92}$ Unfortunately, the Court did not tell us what this "legitimate interest" means and what type of justification is at stake. Instead, it continued explaining how fundamental rights protection needs to be reconciled with fundamental freedoms and it restated that the free movement of goods can be subject to a restriction "for the reasons laid down in Article 36 ... or for overriding requirements relating to public interest, in accordance with the Court's consistent case-law since the judgement in ... Cassis de Dijon". ${ }^{93}$ This paragraph might suggest that the Court in Schmidberger is applying either the first or the second above-mentioned option, but it is certainly not clear which one.

Academic writing reveals different and contradictory understandings of the way in which the ECJ used fundamental rights as a justification in Schmidberger. My stated opinion approximates that of C. Brown who argues that in Schmidberger "there is no attempt to pigeonhole a justification based on need to respect human rights into one of the justificatory

\footnotetext{
90 Commission v France (n 79).

${ }^{91}$ Schmidberger (n 30) para 64.

92 ibid para 74.

93 ibid para 78.
} 
categories" and that it "could therefore be said that the ECJ has in fact invoked (perhaps created) a 'floating' justification, albeit one which is nevertheless subject to the familiar proportionality test". ${ }^{94}$

Catherine Barnard considers that fundamental rights protection constitutes a mandatory requirement. ${ }^{95}$ She argues that the Court in Schmidberger did not see fundamental rights as a public policy derogation, but rather as a "free-standing justification or public interest requirement" ${ }^{96}$ Under this conception, fundamental rights still remain distinct from other mandatory requirements because they are also a general principle of Community law, and other mandatory requirements have to be assessed in their light (Familiapress). ${ }^{97}$ The problem with this solution is that the classical approach of the ECJ does not accept the use of mandatory requirements for the justification of distinctly applicable measures. Under that approach, fundamental rights as a mandatory requirement could only serve as a justification of indistinctly applicable restrictions on free movement. Nevertheless, this might not be a problem since there have already been many cases where the Court blurred the distinction between distinctly and indistinctly applicable measures and between express Article 30 derogations and mandatory requirements. ${ }^{98}$

However, scholars have also argued that the justification of the measure in Schmidberger was neither an Article 30 derogation nor a mandatory requirement, ${ }^{99}$ but rather that the Court was deciding on the hierarchy of fundamental freedoms and fundamental rights, giving primacy to the latter. ${ }^{100}$ I agree that in this particular case the ECJ supported a restriction on the free movement of goods on grounds of protection of the freedom of expression and the freedom of assembly. However, in my view it does not follow from this that freedom of expression and freedom of assembly have been given any general primacy over the free movement of goods. The ECJ emphasised that all of these categories can be restricted and that "the interests involved must be weighed having regard to all the circumstances of the case in order to determine whether a fair balance was struck between those interests". ${ }^{101}$ A fortiori we cannot deduce from

\footnotetext{
${ }^{94}$ Brown (n 73) p 1504.

95 C Barnard, The Substantive Law of the EU - The Four Freedoms (Oxford University Press, Oxford 2004) 109.

96 ibid 70.

97 ibid 117.

98 Case C-2/90 Commission v Belgium [1992] ECR I-4431 (Walloon Waste), C-67/97 Bluhme [1998] ECR I-8033. Barnard (n 95) 117-118.

99 Gonzales (n 74) 223.

100 ibid 226.

${ }^{101}$ Schmidberger (n 30) para 81.
} 
Schmidberger that the ECJ established a clear hierarchy between fundamental rights and fundamental freedoms. ${ }^{102}$

It seems to me that the Court is not inclined to set a firm rule for weighing fundamental rights against fundamental freedoms, but rather that it wants to leave more space for States and for itself to decide these issues on a case-by-case basis. In that respect, an important part of the analysis appears in the Court's scrutiny of proportionality where it is emphasised that both the free movement of goods and the fundamental rights at stake, and the freedom of expression and the freedom of assembly can be limited, ${ }^{103}$ and that the weighing of the interests involved must be done with regard to all the circumstances of the case, and particularly with regard to the fact that the competent authorities enjoy wide discretion in that area. ${ }^{104}$

To conclude the analysis of Schmidberger, the ECJ did not adopt a crystal clear rule on the relationship between fundamental rights and fundamental freedoms which could provide a simple answer in all future cases where they come into conflict. Rather, as Advocate General StixHackl points out, it seems that "[t]he need to reconcile the requirements of the protection of fundamental rights cannot ... mean weighing up fundamental freedoms against fundamental rights per se". ${ }^{105}$ "[T]he necessary weighing up of the interests involved ultimately takes place in the context of the actual circumstances in which the particular fundamental rights are restricted." ${ }^{106}$ This case-by-case approach undoubtedly puts a great deal of responsibility in the hands of national courts, and it is probable that it will cause many new references to the ECJ. ${ }^{107}$

The Court was given another opportunity to explain the relationship between fundamental rights and fundamental freedoms in Omega. ${ }^{108}$ The Omega company operated a laserdrome, and games that were played on this installation included shooting "sensory tags placed on jackets worn by players" with laser beams, and recording the number of shots. ${ }^{109}$ Ger-

\footnotetext{
102 Contrary to Gonzales (n 74) 226.

103 Schmidberger (n 30) para 78-80. In general, I believe that there are areas in which the ECJ is modifying the standard of review over measures caught by Article 28 and making the scrutiny less strict, but this has implications which go beyond the subject matter of this paper and will not be discussed here.

104 ibid paras $81,82$.

105 Opinion of Advocate General Stix-Hackl in Omega (n 6) para 53.

106 ibid para 53.

107 Brown (n 73) 1510.

108 For a comment on Omega, see T Ackermann, 'Case C-36/02, Omega Spielhallen- und Automatenaufstellungs-GmbH v. Oberbürgermeisterin der Bundesstadt Bonn, Judgment of the Court of Justice (First Chamber) of 14 October 2004, nyr' (2005) 42 CMLRev 1107.

109 Omega (n 31) para 5.
} 
man authorities considered this game to imitate killing people and issued an order forbidding Omega to facilitate or allow the playing of this game in its establishment. The question that reached the ECJ was whether the prohibition at stake was incompatible with the freedom to provide services and the free movement of goods. As the issue of the free movement of goods (i.e. that of the laserdrome equipment) in this case was merely secondary and attached to the freedom to provide services, the Court examined the issue only regarding services and found that the provision of services was affected. ${ }^{110}$

In justifying the measure, German authorities called upon the protection of human dignity guaranteed by the German Constitution and upon public policy. It is worth pointing out that human dignity within the German constitution is not merely a constitutional principle, but rather an independent fundamental right. In contrast, human dignity in international documents and in the national legal systems of other Member States "seems to appear ... as a general article of faith or ... as a fundamental evaluation or constitutional principle, rather than as an independent justiciable rule of law". ${ }^{111}$ The national court inquired in that respect whether "a common legal conception in all Member States is a precondition" for restricting a fundamental freedom.

While the Court held that it is not necessary to have a common legal conception for justifying a national restriction on the freedom to provide services, it still did not treat human dignity as a separate human right. It held that since both fundamental rights and human dignity are a part of the general principles of Community law, it was "immaterial ... that ... in Germany ... the principle of respect for human dignity has a particular status as an independent fundamental right". ${ }^{112}$ Therefore, the Court included human dignity into the concept of public policy, which was expressly provided for by Article $46 \mathrm{EC}$ as a permissible derogation from the freedom to provide services, and it discussed these issues jointly.

The approach in Omega is not without problems in respect of weighing national values against fundamental freedoms. Firstly, it is still impossible to conclude whether the protection of all human rights falls within the public policy category. Namely, it is possible that the ECJ would treat the issue differently if human dignity was recognised as a fundamental right by the common constitutional traditions of Member States, since the concept would then enjoy the status of a fundamental right within Community law. This is also suggested in the opinion of Advocate General Stix-Hackl who points out an important methodological

110 This was in accordance with the Court's previous case law. Omega (n 31) paras 25-27.

111 Opinion of Advocate General Stix-Hackl in Omega (n 6) para 84.

112 Omega (n 31) para 34. 
difference between, on the one hand, a fundamental right which is specific for one Member State, and, on the other hand, fundamental rights common to all Member States. The latter category, fundamental rights recognised by the common constitutional traditions of Member States, is a part of the Community system of fundamental rights protection. In that case, "it would no longer be necessary to examine whether the national measure is to be considered a justified, because permissible, exception to the fundamental freedoms enshrined in the Treaty, but, according to the Schmidberger judgement, how the requirements of the protection of fundamental rights in the Community can be reconciled with those arising from a fundamental freedom enshrined in the Treaty". ${ }^{113}$ According to the opinion of Stix-Hackl, human dignity had to be evaluated as part of public policy because the concept is of an inchoate nature, so it was impossible for the Court to "equate the substance of the guarantee of human dignity under the German Basic Law with that of the guarantee of human dignity as recognised by the Community". ${ }^{114}$ Consequently, while it is not clear from the judgement in Omega, the opinion of the Advocate General in the case suggests that other fundamental rights, recognised by the common constitutional traditions of the Member States, would not be considered as part of the public policy exception, but rather as an independent justification for the restriction of fundamental freedoms.

The judgement in Omega appears to me as a continuance of the longlasting tensions between the ECJ and the German Constitutional Court, Bundesverfassungsgericht, regarding the issue about who has competence to enable a balance to be ultimately struck between a fundamental right and a fundamental freedom. ${ }^{115}$ The position of the ECJ is that for the reasons of uniformity and efficacy of Community law, the validity of EC measures cannot be judged with recourse to the legal rules or concepts of national law, but only in the light of Community law. ${ }^{116}$ Therefore, a state cannot derogate from the fundamental freedoms by simply calling upon its constitutional rights and principles, such as human dignity. In contrast, national constitutional courts would no longer observe Community law and the judgements of the ECJ if those were not respectful of national constitutions. The German Constitutional Court made this clear in 1974 in its famous judgement known as Solange I where it held that in the hypothetical case of a conflict between Community law and the Ger-

\footnotetext{
113 Opinion of Advocate General Stix-Hackl in Omega (n 6) para 72.

114 ibid paras 92-93.

115 For a discussion of Kompetenz-Kompetenz in connection to the Omega case, see CT Smith and T Fetzer, 'The Uncertain Limits of the European Court of Justice's Authority: Economic Freedom versus Human Dignity' (2004) 10 Columbia Journal of European Law 445.

${ }^{116}$ Internationale Handelsgesellschaft (n 39) para 3.
} 
man constitutional guarantees of fundamental rights, the constitutional guarantees would prevail for as long as the conflict remained unresolved by the Community. ${ }^{117}$ In the years following Solange I, the EC developed its own system of fundamental rights protection which the Bundesverfassungsgericht considered satisfactory. Consequently, in 1986, in Solange II, it stated that "so long as the European Communities, and in particular the case law of the European Court, generally ensure an effective protection of fundamental rights ... which is to be regarded as substantially similar to the protection of fundamental rights required unconditionally by the Constitution, and in so far as they generally safeguard the essential content of fundamental rights, the Federal Constitutional Court ... will no longer review such legislation by the standard of the fundamental rights contained in the Constitution". ${ }^{118}$ Hence, it was always in the best interest of the ECJ and the Community as a whole for the Court to provide an "effective" and "substantially similar" protection of fundamental rights contained in the German constitution.

So, to return to the facts of Omega, while it was not necessary for the ECJ to treat human dignity as an independent human right, it was still necessary to protect it "effectively" and "substantially similarly" to the way it was protected by the German Constitution. The ECJ managed to provide this level of protection by stating that human dignity is a general principle of law, that in the given circumstances its protection was a part of public policy, ${ }^{119}$ and, furthermore, the Court left enough discretion to the national authorities so that they could prohibit the service at stake as contrary to human dignity.

To conclude the analysis of Schmidberger and Omega, these cases demonstrate how committed the EU is to fundamental rights protection.

117 (1974) 2 CMLR 540, 549-50. "Vorläufig entsteht also in dem unterstellten Fall einer Kollision von Gemeinschaftsrecht mit einem Teil des nationalen Verfassungsrechts, näherhin der grundgesetzlichen Grundrechtsgarantien, die Frage, welches Recht vorgeht, das andere also verdrängt. In diesem Normenkonflikt setzt sich die Grundrechtsgarantie des Grundgesetzes durch, solange nicht entsprechend dem Vertragsmechanismus die zuständigen Organe der Gemeinschaft den Normenkonflikt behoben haben.”, BVerfGE 37, 271 - Solange I, decision of 29 May 1974 <http://www.oefre.unibe.ch/law/dfr/bv037271.html>.

118 (1987) 3 CMLR 225, 265. "Solange die Europäischen Gemeinschaften, insbesondere die Rechtsprechung des Gerichtshofs der Gemeinschaften einen wirksamen Schutz der Grundrechte gegenüber der Hoheitsgewalt der Gemeinschaften generell gewährleisten, der dem vom Grundgesetz als unabdingbar gebotenen Grundrechtsschutz im wesentlichen gleichzuachten ist, zumal den Wesensgehalt der Grundrechte generell verbürgt, wird das Bundesverfassungsgericht seine Gerichtsbarkeit über die Anwendbarkeit von abgeleitetem Gemeinschaftsrecht, das als Rechtsgrundlage für ein Verhalten deutscher Gerichte oder Behörden im Hoheitsbereich der Bundesrepublik Deutschland in Anspruch genommen wird, nicht mehr ausüben und dieses Recht mithin nicht mehr am Maßstab der Grundrechte des Grundgesetzes überprüfen” BVerfGE 73, 339 - Solange II, decision of 22 October 1986, <http://www.oefre.unibe.ch/law/dfr/bv073339.html>.

119 Omega (n 31) paras 34 and 32. 
They also shed new light on the reasoning introduced in Internationale Handelsgesellschaf and Nold where the Court held that this protection was inspired by the common constitutional traditions of Member States ${ }^{120}$ and by "international treaties for the protection of human rights on which the Member States have collaborated or of which they are signatories". ${ }^{121}$ Schmidberger and Omega illustrate how broad the implications of this reasoning are, since fundamental rights can be invoked even for limiting the application of Treaty rules on fundamental market freedoms.

\section{Conclusion}

The development of the Community system of fundamental rights was primarily led by the ECJ, and we can assume that this was a necessary corollary of the fact that the European legal order had started presenting new restraints on national sovereignty, especially through direct effect and supremacy. Member States would not have been willing to accept such characteristics of the Community legal system if that system was not at least bound by the protection of fundamental rights. Today, the Union has a complex system of fundamental rights and, on the one hand, there are instances where the ECJ can review whether a Member State is observing those rights and, on the other hand, situations exist where Community law permits States to derogate even from fundamental freedoms in order to protect fundamental rights. Concerning the interaction of fundamental rights with fundamental market freedoms, the Court for a long time had to decide only cases where these two categories went hand in hand, but recently we have seen cases where they have been in conflict. It is important to notice that in both types of cases the ECJ showed deference to the protection of fundamental rights, but the problem is that it seemed to lack concern for other interests that national regulators seek to protect.

Regarding the first type of cases where fundamental rights and fundamental freedoms worked to each other's advantage, the main question is how to leave the States enough leeway for the protection of the other interests involved (e.g. control over immigration). In that respect, it must be noticed that the limits of the Treaty provisions on free movement (such as those introduced in the sphere of goods by the Keck ${ }^{122}$ and Krantz line of case law) are relevant not only because they generally allow States more regulatory autonomy, but also because they limit the possibility of the ECJ to guard fundamental rights. In other words, the scope of the

\footnotetext{
${ }^{120}$ Internationale Handelsgesellschaft (n 39) para 4.

${ }^{121}$ Nold (n 39) para13.

122 Joined cases C-267/91 \& C-268/91 Criminal proceedings against Keck and Mithouard [1993] ECR I-6097.
} 
Treaty articles on fundamental freedoms "partly determines the scope of fundamental rights protection given by the ECJ against Member States' action", ${ }^{123}$ so, for example, limiting the scope of Article 28 EC reduces "the number and type of national measures that can be reviewed under the fundamental rights affirmed by the Court of Justice". ${ }^{124}$ As I have argued elsewhere, ${ }^{125}$ this scope of Treaty provisions on free movement should be taken seriously, and it should not be extended merely to bring a situation involving human rights into the field of application of Community law. However, the Carpenter case raises concerns that the reality might be quite the opposite and under that scenario the States would be left with very little space for national regulation aimed at the protection of other interests. Further application of the reasoning adopted in Carpenter as well as Karner might result in the lowering of national standards (for example of immigration control), which would be particularly frightening in areas where the Community lacks competence to replace national measures. However, this does not mean that there is no more space for developing synergies between fundamental rights and fundamental freedoms. A good example of where this could be done was discussed above in connection with the opinion of Advocate General Maduro in Carbonati Apuani.

It is certainly not easy to precisely determine where to draw the line in guarding fundamental freedoms and fundamental rights, but it should be borne in mind that the ECJ is neither a court of human rights nor a national constitutional court and that it has no independent jurisdiction to decide on human rights violations, ${ }^{126}$ as was recently confirmed in Vajnai Attila. ${ }^{127}$ One should not try to circumvent this lack of jurisdiction by broadening the scope of market freedoms in order to bring a situation within Community law so that the Court could adjudicate on human rights protection. "The potential for fundamental rights litigation is enormous under the present case law of the Court in the rules of free movement", ${ }^{128}$ but should not be abused. Interpreting Treaty rules on market freedoms too broadly could jeopardise the functioning of the entire Community legal system. It could make the workload of the ECJ unmanage-

\footnotetext{
${ }^{123}$ Maduro (n 32) p 312.

124 ibid 312.

${ }^{125}$ T Perišin, 'Balancing Sovereignty with the Free Movement of Goods in the EU and the WTO - Non-Pecuniary Restrictions on Free Movement of Goods' (2005) 1 Croatian Yearbook of European Law; T Perišin, 'Admissibility of National Measures in Relation to Free Movement in the European Union' (2003) Journal of the Faculty of Law in Zagreb (Zbornik Pravnog fakulteta u Zagrebu)

${ }^{126}$ See ERT (n 15), SPUC $v$ Grogan (n 18) and case 5/88 Hubert Wachauf v Bundesamt für Ernährung und Forstwirtschaft [1989] ECR 2609.

127 Vajnai Attila (n 70) paras 12-14.

128 Maduro (n 32) 313.
} 
able, disable necessary national regulation, and threaten the legitimacy of the Community's legal system.

Concerning the second type of cases, where fundamental rights and fundamental freedoms are in conflict, the analysis demonstrates that the ECJ has not adopted a clear test for weighing these interests, and, furthermore, the Court is not engaged in balancing these categories. Rather, the Court appears to be adopting a case-by-case approach where balancing is done with regard to the circumstances of the case. The advantage of such a solution is its flexibility and the possibility of taking into consideration Member States' specificities. The Court is sensitive to national regulatory choices, so national authorities are given significant discretion in achieving their desired level of human rights protection. The main drawback of the current approach is that we do not know in which category of justification for trade restrictive measures human rights belong. Do they belong to Article 30 derogations, a mandatory requirement, or perhaps to a new type of justification? The answer to this question would be particularly relevant in cases where human rights are invoked to justify a discriminatory restriction on the free movement of goods, since not all types of justification can be used in such cases. Another problem with not having a clear approach on weighing fundamental rights against fundamental freedoms is that national courts might hesitate in deciding on these questions, and this might stimulate many new references to the ECJ. All this requires a more precise test, but a test which would remain flexible enough not to impair national standards of human rights protection. I would certainly recommend making it clear that fundamental rights are a type of justification for restrictions of market freedoms which can be used both for saving distinctly and indistinctly applicable measures (whether a special type of justification, a part of Article 30, or even a mandatory requirement, provided that the field of application of mandatory requirements is extended).

It can easily be imagined that following Schmidberger and Omega many new cases could arise in which a fundamental right or a fundamental principle would be called upon to justify a derogation from a fundamental market freedom. In that respect, it should be noted that the Charter of Fundamental Rights contains both rights and principles, ${ }^{129}$ so

\footnotetext{
${ }^{129}$ It is not entirely clear what the difference between rights and principles is, and which concepts fall within which of these two categories.

The Charter says that principles shall be observed (art 51), and the Working Group of the European Convention which analysed the possibility of inserting the Charter into the Constitutional Treaty proposed adding a paragraph into the Constitutional text of the Charter saying that principles "may call for implementation through legislative or executive acts; accordingly, they become significant for the Courts when such acts are interpreted or reviewed" (Final report of the Working Group II "Incorporation of the Charter / accession to the ECHR", CONV 354/02, 22 October 2002, at p 8). In contrast, it seems that rights are
} 
it seems that all the categories mentioned in this document could potentially authorise derogations from fundamental market freedoms. ${ }^{130}$ For example, in order to justify the mandatory use of an official language on product labels, a State could not only call upon public health and consumer protection if these were applicable, but also on linguistic diversity which is guaranteed by Article 22 of the Charter (as well as by Article 151 EC on cultural diversity). ${ }^{131}$ It remains to be seen whether this is the path that the Court will follow.

justiciable. The text of the Charter which is incorporated in the Constitution is amended in this part. The new provision embodied in art II- 112 provides that "the provisions of this Charter which contain principles may be implemented by legislative and executive acts taken by institutions, bodies, offices and agencies of the Union, and by acts of Member States when they are implementing Union law, in the exercise of their respective powers. They shall be judicially cognisable only in the interpretation of such acts and in the ruling on their legality".

However, how to determine which concept is a right and which is a principle? One solution is to analyse the wording of the article in order to determine whether its purpose is to impose an obligation upon the Union and the Member States or to grant rights to individuals. For example, if one looks at article 37 on environmental protection, it is clear that it contains a principle. However, with many provisions the situation is more difficult. For example, equality between men and women is expressed in article 23 as a principle, while the case law clearly demonstrates it contains a justiciable right. In contrast, the rights of the elderly (article 25) and the rights of persons with disabilities (article 26) are actually principles, although the Charter refers to them as rights.

${ }^{130}$ It is true that the Charter is not legally binding and, arguably, the Charter only reaffirms rights that are already recognised in the legal order of the Union. It is written in the Preamble that the "Charter reaffirms ... the rights as they result ... from the constitutional traditions and international obligations common to the Member States, the Treaty on European Union, the Community Treaties, the European Convention for the Protection of Human Rights and Fundamental Freedoms, the Social Charters adopted by the Community and by the Council of Europe and the case-law of the Court of Justice of the European Communities and of the European Court of Human Rights". For an analysis of the arguments in favour of considering that the Charter contains many novelties for fundamental rights protection, see T Perišin, 'Human Rights Protection under the EU Constitution (Zaštita ljudskih prava po Ustavu Europske unije)' (2005) 5 Journal of the Faculty of Law in Zagreb (Zbornik Pravnog fakulteta u Zagrebu).

${ }^{131}$ I am grateful to Stephen Weatherill for pointing this out to me. 